\title{
鼓室形成術の基本手技
}

\author{
東京慈恵会医科大学耳鼻咽喉科
}

山本裕

はじめに

鼓室形成術は, 中耳腔（鼓室腔と乳突腔）の病変の清掃，再建等を行う一連の操作の総称として用いられる ${ }^{122)}$. 従つ て本手術に包括される目的と手技は多岐に渡る。本稿では顕微鏡下で行う鼓室形成術の手術のポイントを手技の総論, 重要藏器周囲操作時の留意点, 再建時の留意点に分けて概説する.

\section{手技総 論}

1. 準備

手洗いの前に手術室全体を見渡して環境を整える。手術台, 各種機器, 無影灯の最適な位置関係を構築する. 顕微 鏡，録画システム，画像モニターの設定など可能なことは麻酔導入中に済ませておく．

麻酔導入後，術側を最終確認した後に適切な体位をとる。頭部の長軸が水平になるように，また側頭骨の坦面が術者 の視軸に垂直になるように調整する。神経刺激・モニター装置を用いる場合は，適切な位置への針電極の刺入，固定を 行いインピーダンスが適切かを必ずチェックしておく.

手洗い消毒の後，美しいシーツ掛けを行う。皮切ラインに対して必要十分な術野が確保されていること，頭髮がはみ 出していないことを確認する.

2. 術野の作成, 展開

皮膚切開, 骨膜切開は一律ではなく，施行する手術の術野の展開に必要十分なものでなければならない。骨膜が剥離 され，側頭骨外側が露出した時点で，側頭骨外側の解剖学的なランドマークを確認し再度術野の空間軸を設定する (図 1 )。これらの軸を意識しながら術中のあらゆる操作を行うことが極めて重要となる.

3. 軟部組織の剥離操作

外耳道皮膚，鼓膜，真珠腫上皮，肉芽などの軟部組織の剥離は中耳手術で最も基本的な操作だが，剥離するレイヤー によって操作は異なる，骨組織から粘膜，骨膜ごと剥離する場合は器具が骨面に直接あたるように操作する。一方，粘

a

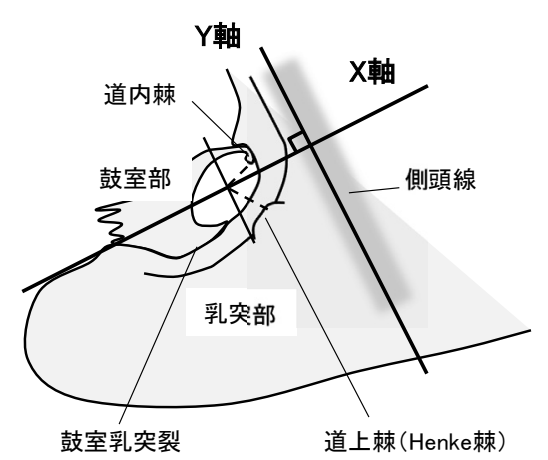

b

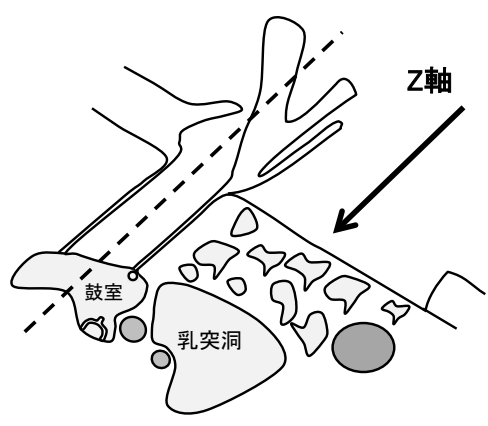

図 1 術野の空間軸の設定

側頭骨外側のランドマークを確認して術野の軸を設定する.

$\mathrm{a}$ ：側頭線, 道上棘, 道内棘, 鼓室乳突裂などを頼りにXY 軸を決定する.

$\mathrm{b}$ ：外耳道の軸に平行に $Z$ 軸を設定する. 


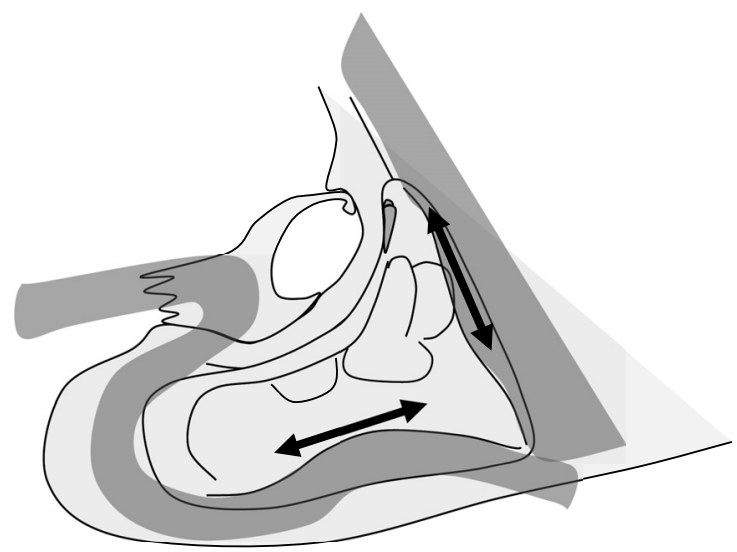

図 2 ドリリングの方向

中頭蓋窩, S 状静脈洞などの重要臓器に対して平行にバーを動かすことが重要である.

膜，骨膜などの軟部組織を深部に残して剥離を行う場合は，剥離面を強拡大でよく観察しながらソフトタッチで剥離を すすめる．しかし癒着が強く剥離が困難な場合は，マイクロメスなどを用いて鋭的に切離することも必要となる．どの ような剥離を行うべきかをしっかり見極めて適切な手技を用いることが重要である.

4. ドリリング

ドリルは基本的にペンホルダーで持つが，ぶれないように手首や前腕を術野に固定する。バーはドリリングの序盤で はなるべく大きいものを用いて媣部に行くに従ってサイズを適時小さくしていく．重要臟器に対して平行にバーを動か すことが基本となる（図 2 ）。またカッティングバーとダイアモンドバーの特性の違いをよく理解して, 適切に使い分 けること, 温度上昇による組織障害やバーの目詰まりの防止のため十分なイリゲーションを行うことも重要である ${ }^{3)}$.

骨構造の中に重要臟器が潜んでいる中耳手術では, 時に解剖学的な位置関係を失認することがある，その場合はダイ アモンドバーで積極的に骨組織を薄くして, 背後の組織を透見できるようにして位置関係を弱拡大で確認するという姿 勢（Positive identification）も重要である.

5. 吸引操作

耳科手術のほとんどの場面で左手の操作は吸引管により行うことになる. 穴のあるなしや太さの使い分けを種々の場 面で行う．大きいカッティングバーでドリリングを行っている場合には，太めの吸引管でイリゲーションを吸引しつ つ, バーが逸脱して重要藏器にあたることがないように吸引管でプロテクトすることも重要となる。一方，軟部組織を 吸引により把持する場合は組織がちぎれないように極細の吸引管で穴を押さえずに使用するなど種々のテクニックを身 に着ける。

6. 止血と洗浄

常に術野に出血がない状態を保ちながら手術を進行させたい. そのためには出血がみられるたびに洗浄と止血操作を 繰り返し行う。浅部の軟部組織の止血は電気メスで行うが，深部では顔面神経や内耳への障害を配慮する必要がある。 すぐに止血が得られない場合には深追いはせずエピネフリン液を浸したガーゼで圧迫し，その操作はいったん保留とし てほかの操作を先行させる姿勢も重要である。骨面からの出血は骨蛕やダイアモンドバーによる研磨が有効である.

1. 顔面神経

\section{重要臓器周囲の手術手技}

側頭骨内を走る顔面神経の走行を三次元的に理解することがまず重要となる（図 3 ). 術前に側頭骨 CT 画像をよく 吟味して, 病変と顔面神経管との関係, 骨欠損の有無をよく検討しておく．特に真珠腫症例においては，膝部の外側， 水平部, 垂直部で露出が多く注意を要する. 膝部では真珠腫の剥離を乳突洞から上鼓室に進める時に, 水平部ではアブ ミ骨周囲の操作時に, 垂直部では外耳道後壁削除時に損傷しやすい. 基本的な剥離操作は神経の走行に沿って行うよう に心がける．また神経刺激・モニターを積極的に使用する．耳小骨の先天異常症例では神経の走行異常を伴うことがあ るので特に注意を要する4). 


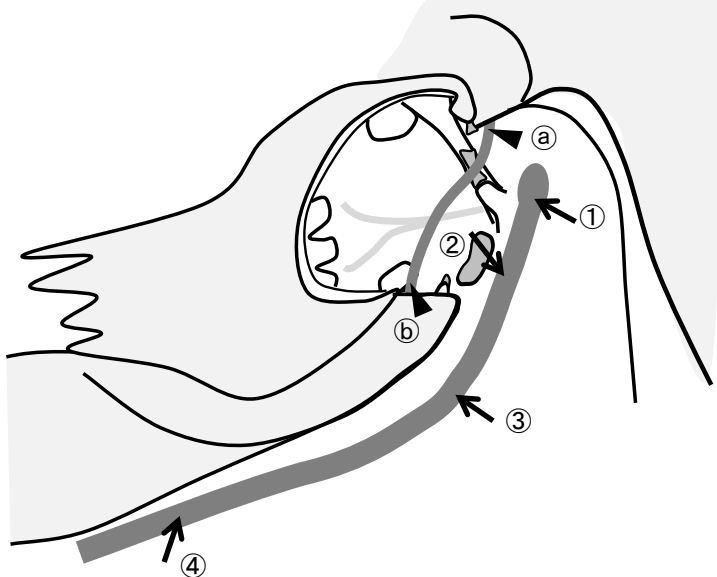

図 3 顔面神経, 鼓索神経の走行と特に注意を要する 部位

両神経の 3 次元的な走行を理解する。顔面神経 では, (1) 膝神経節外側, (2) 水平部, (3) 第二 膝部, (4) 垂直部で, 鼓索神経では, (a)ツチ骨 前方, (b) 中鼓室後方で特に注意が必要となる.

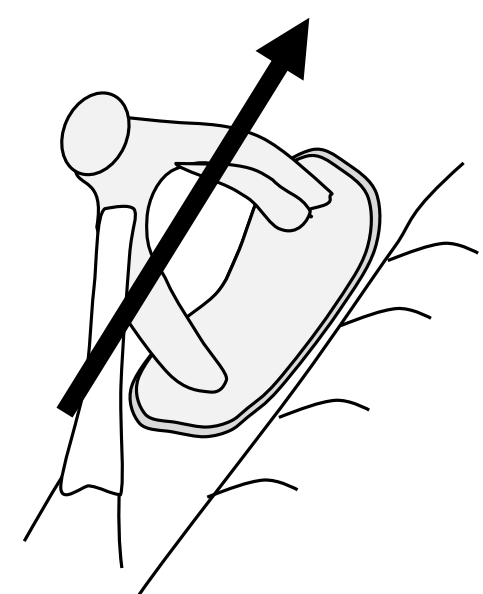

図 4 アブミ骨周囲の操作

脱臼や内耳障害を防止するために，底板の長軸に 沿って前方側へ操作を行うように心がける.

\section{2. 鼓索神経}

鼓膜の挙上剥離時, scutum の削開時, ツチ骨骨頭の切除時に損傷しやすいので神経の走行を十分理解することが重 要となる (図 3 )。軟部組織との剥離ではあえて鋭的に操作を行い牽引を避けること，また乾燥を防止することにも留 意する.

3. 頭蓋窩, S 状静脈洞

サイズが小さいカッティングバーで一部のみが深くなるような削開を行ったときに損傷が起こりやすい. 接近する前 に大きなダイアモンドバーを走行に平行に動かしながら削開するように留意する（図 2 ).

4. 耳小骨周囲

連鎖が保たれている症例では，バーが接触しないように注意する。もし操作上心配がある場合には積極的に連鎖をは ずしてからドリリングを進める，アブミ骨周囲の病変除去時には，顔面神経水平部に注意しながら，操作の方向がなる ベく底板の長軸に沿った前方に向かうようにして底板の脱臼防止に配慮する（図 4 ）.

\section{再建のための手術手技のポイント}

\section{1. 鼓膜形成}

鼓膜形成は側頭筋膜などの材料を挿置する位置により，overlay，inlay， undelayに分けられる。詳細は成書に譲る が，いずれの術式においても最も重要となるのは，すべての操作が明視下に行われるように十分な術野を確保すること である．特に鼓膜穿孔の前縁は視野が確保しづらいため, 不完全な視野による操作が術後の再穿孔を引き起こすことも 少なくない，顕微鏡の視軸を動かして最適な視野を確保するとともに，必要に応じて骨部外耳道後壁，下壁の入口部を 肩を落とすように削開することが重要である，前壁の突出が高度な場合は前壁の皮膚を別途剥離した後に骨を削開する ことも考慮する.

2. 耳小骨連鎖再建

耳小骨連鎖再建を成功に導くために重要となるのは, 病態の把握, 術式の選択, 材料の加工と挿置を適切に行うこと に尽きる。

まず先入観にとらわれずに耳小骨の連続性，可動性をチェックし，それに対する適切な術式の選択を行う。その際に は残存耳小骨や鼓膜との位置関係を実際に計測しながら評価するように心がける．それに基づいた立体的な設計の基に 材料を適切に加工する (図 5$)^{5)}$. 内耳障害が生じることのないように配慮しながら材料を適切な位置に挿置し, 可動 


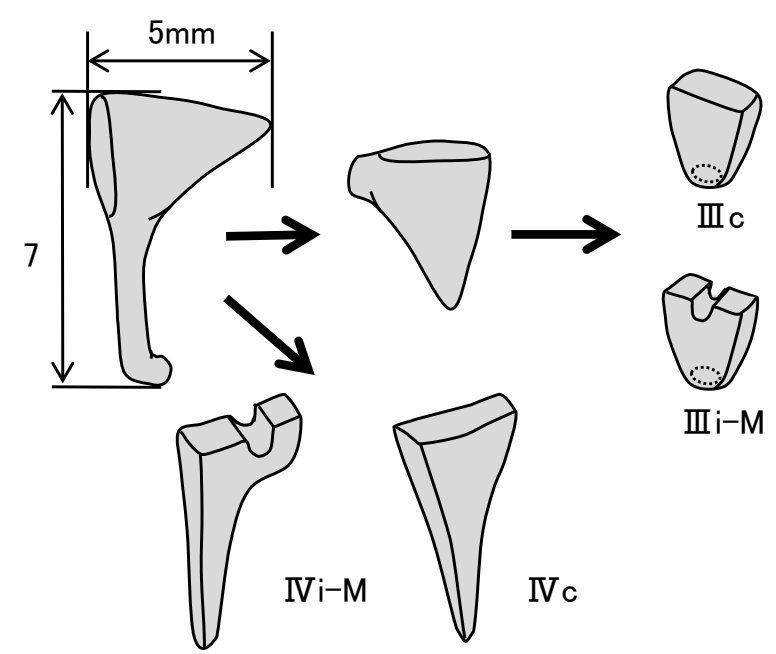

図 5 キヌタ骨の再利用による再建材料の加工例

キヌタ骨短脚の利用により III型の材料が，長脚を含めた利用により IV型の材料が加工できる.

性, 連続性を確認しながら適切な位置で固定する。

3. 上鼓室側壁や外耳道後壁の再建

主に真珠腫性中耳炎では, 外耳道後壁保存型鼓室形成術では上鼓室側壁の再建が, 外耳道後壁削除型鼓室形成術では 外耳道後壁の再建がしばしば行われる。そこでは再形成真珠腫の防止のために術者によって種々の工夫が施されるが, 共通する事項として再建材料を安定させ, 再陥凹しないようにすること, 段差が生じないようにすることが重要とな $ろ^{677)}$. 材料の候補としては，軟骨，皮質骨，骨パテなどがあるが，選択や使用方法は術者によりさまざまである。それ ぞれの利点・尔点を考慮して最善の方法を選択するようにしなければならない.

\section{ま と め}

鼓室形成術では病変の除去, 再発の防止と聴覚機能の温存や改善を両立させなければならない. そのために術者が準 備しなければならない手技は多様である。それぞれの場面で用いる手技を整理して習熟する必要がある。また側頭骨の 手術解剖に精通することが必要なのは言うまでもない. そのためにはご遺体を用いた手術手技研修, 3 次元モデルを用 いた実習などを積極的に活用することが重要である.

\section{参 考文 献}

1）東野哲也, 青柳 優, 伊藤 吏, 他：上鼓室・乳突腔病巣処理を伴う鼓室形成術の術式名称について（2010)一日本耳科学 会用語委員会報告一. Otol Jpn 2010；20：748-750.

2）東野哲也, 青柳 優, 伊藤 吏, 他: 伝音再建法の分類と名称について（2010）一日本耳科学会用語委員会報告一. Otol Jpn $2010 ； 20$ : 746-748.

3）須納瀬＼cjkstart弘： canal wall up 法による乳突削開. JOHNS 2013；29：185-188.

4) 山本 裕：耳小骨奇形の病態と連鎖再建術. 日耳鼻 $2013 ; 116: 69-76$.

5）山本＼cjkstart裕：耳小骨連鎖再建術の成績と改善策. Otol Jpn 2007；17：51-54.

6) Yamamoto Y, Takahashi K, Morita Y, et al : Long-term follow-up results of canal wall down tympanoplasty with mastoid obliteration using the bone pate plate for canal wall reconstruction in cholesteatoma surgery. Otol Neurotol 2014 ; 35 : 961-965.

7）山本 裕：【私はこうしている一耳科手術編】中耳手術 後天性真珠腫性中耳炎 後壁削開の立場から. JOHNS 2016；32： 1195-1197. 